\title{
O MITO DA CONSPIRAÇÃO JUDAICO-COMUNISTA
}

\author{
Rodrigo Patto Sá Motta \\ Depto. de História da UFMG \\ Doutorando em História-FFLCH/USP
}

RESUMO: O artigo analisa a construção do mito da conspiração judaico-comunista, encarando-o como ponto de interseção entre os movimentos anti-semita e anti-comunista do século XX. A proposta é relacionar o fenômeno às tensões provocadas pelo processo de modernização e transformação revolucionária das sociedades contemporâneas.

ABSTRACT: The article analyses the existence of a jewish-communist conspiration myth, faced as an intersection point between XX century's anti-semitism and anticommunism movements. The aim is to show the links between the myth and the processes of modernization and revolutionary transformation affecting contemporary societies.

PALAVRAS-CHAVE: História, Política, Mitologia, Anticomunismo, Anti-semitismo

KEYWORDS: History, Politics, Mythology, Anticommunism, Anti-semitism

\section{Introdução}

O objetivo central deste trabalho é analisar um aspecto muito importante, porém pouco explorado do anti-semitismo, a questão da relação entre os judeus e o comunismo. A associação da militância revolucionária e do comunismo à figura do judeu apresentado como artífice máximo do "perigo vermelho" - foi um dos desdobramentos mais curiosos e instigantes da pregação anti-semita, tendo levado ao estabelecimento de um construtor mitológico sobre a existência de uma suposta conspiração dos judeus visando instaurar a ditadura comunista. Tal fenômeno também poderia ser interpretado, por outro lado, como uma derivação do anticomunismo, ideário igualmente produzido pelo pensamento conservador. A posição mais adequada, porém, é entender o mito da conspiração judaico-comunista como um ponto de interseção entre anti-semitismo e anticomunismo, dois fenômenos profundamente ligados aos desdobramentos do mundo contemporâneo. Ao longo do texto analisaremos a emergência do mito em questão, tentando mostrar que seu surgimento está diretamente ligado às tensões 
provocadas pelo advento da modernidade e do processo de modernização.

Neste sentido, é de fundamental importância destacar as mudanças vivenciadas pelo anti-semitismo ${ }^{1}$ nos últimos cem anos. No século XIX os círculos reacionários já denunciavam os judeus como instigadores de perturbações sociais e de revoluções, mas a questão comunista não estava colocada de maneira clara. Foi somente no século XX, notadamente após a eclosão da Revolução de 1917 e dos movimentos fascistas, que se caracterizou efetivamente a junção entre comunismo e judaísmo a nível do discurso conservador, passando a ser disseminado em larga escala o mito da conspiração judaico-comunista.

No decorrer do trabalho faremos uma abordagem aprofundada do referido mito, procurando entender sua gênese e desenvolvimento através da análise do discurso e da iconografia responsáveis por sua constituição. Ao final tentaremos responder a duas questões, fundamentais quando se trata de interpretar as mitologias modernas: "a quem ou a que servia o mito" e "como se explica a sua larga aceitação"?

\section{O mito conspirativo, uma tentativa de teorização}

Há, basicamente, três conceituações possíveis para Mito: a mais antiga relaciona o conceito a narrativas fabulosas, normalmente sagradas, relacionadas a um tempo imemorial. A narrativa mitológica seria portadora de uma explicação para a origem do mundo e para a ordem social vigente e também traria

\footnotetext{
${ }^{1}$ Nos ateremos exclusivamente às manifestações anti-semitas contemporâneas, que deslocam o tradicional argumento religioso, substituído por considerações de natureza política e 'racial'. De certo modo é redundante falar-se em anti-semitismo contemporâneo, pois esta expressão não existia em períodos anteriores. Ela foi cunhada exatamente para expressar uma realidade nova, a emergência de um preconceito contra os judeus motivado por questões políticas e raciais.
}

em seu bojo a divulgação de ensinamentos morais (ELIADE,1972, p.7-13). Outra definição corrente: o mito como pura mistificação, ilusão, camuflagem. Neste sentido, haveria uma incompatibilidade entre mito e realidade. Por fim, a concepção atribuída a Georges Sorel, mais sensível à compreensão da força das mitologias nas sociedades modernas. O mito seria uma construção dinâmica que incitaria à ação, à liberação da energia social. O exemplo mais óbvio neste caso seria o mito revolucionário (GIRARDET, 1987, p.13).

Na verdade, o mito político moderno, categoria na qual se enquadra o nosso objeto de análise, possui elementos das três definições citadas. É uma narrativa que elabora uma explicação para a realidade social, contém uma série de mistificações e propõe um programa de ação. A construção mitológica que vamos analisar procura explicar as transformações vividas na modernidade como tendo sido provocadas por uma conspiração judaico-comunista, clara operação mistificadora da realidade, e propõe o combate sem tréguas ao judaísmo e ao "judeo-bolchevismo", visando neutralizar a ação maléfica dos supostos conspiradores.

O mito da conspiração mundial judaica, na realida$\mathrm{de}$, se insere num quadro mais amplo que o explica e lhe confere significado. No período contemporâneo tornaram-se correntes mitologias de conspirações políticas, sendo a versão "judaica" apenas uma entre várias.

A Revolução Francesa parece ter sido a parteira dos mitos conspirativos, no seu bojo foram engendrados os primeiros modelos de uma longa série de conluios: a conspiração da fome e a conspiração dos aristocratas, por exemplo (LEFEBVRE, 1979).

Contudo, os exemplares mais clássicos da mitologia conspirativa - e de mais fértil disseminação ao longo dos séculos XIX e XX - são a conspiração maçônica, a jesuítica e a judaica. Nos três casos, o enredo é basicamente o mesmo, embora mudem as personagens e o cenário: tratar-se-ia de conspirações secretas, conduzidas por um grupo reduzido de pessoas misteriosas e assustadoras, inspiradas por maus 
desígnios. Ora aos maçons, ora aos jesuítas, ora aos judeus, dependendo da versão, era atribuída a responsabilidade pela condução dos destinos do homem moderno, encarado como mera vítima frente à atuação de formidáveis forças secretas e sinistras. Os conspiradores, agindo nas sombras e lançando mão de artifícios camuflados, seriam os verdadeiros culpados pelos diversos males vividos no mundo moderno. Obviamente, o entendimento acerca do mal poderia variar, dependendo do ponto de vista dos grupos sociais "emissores" ou "receptores" das mitologias, se é que se pode estabelecer tal distinção (GIRARDET, 1987).

Como interpretar a ocorrência de tais fenômenos e, principalmente, como entender a força de persuasão de tais mitos, demonstrada pelo poder de atração exercido sobre milhões de seres humanos nos dois últimos séculos? Como analisar a surpreendente realidade de que tantas pessoas, muitas delas integrantes do mundo da alta cultura, acreditaram (e alguns ainda acreditam), simploriamente, que os males existentes no mundo se deviam à ação maligna de um punhado de conspiradores?

De maneira geral, podemos afirmar que a recorrência dos mitos conspirativos se deve a uma reação à modernidade e ao processo correlato de "desencantamento do mundo". Para vastos setores sociais, a modernização e a modernidade desencadearam transformações vivenciadas com angústia e medo. Tais mudanças experimentadas pelo mundo contemporâneo - urbanização, industrialização, surgimento e fortalecimento de novos grupos sociais, reformas liberais e democratizantes, alterações no comportamento, etc. - provocaram tensões muito fortes sobre o tecido social, levando muitos segmentos, normalmente identificados com o status quo anterior, a encararem-nas como negativas. Longe de sentirem as inovações como libertadoras e promissoras, perceberam-nas como destrutivas e maléficas: estaria ocorrendo um processo de decadência e degenerescência da civilização (WEBER, 1988). Ressalte-se, a reação negativa não era uma exclusividade dos grupos privilegiados. Muitos indivíduos de origem humilde também vivenciaram a modernização como perda, encarandoa como culpada pelo empobrecimento e aumento da exploração. $\mathrm{O}$ fato é que a sensação de mal-estar, o medo e a insegurança afetaram a largas camadas sociais, notadamente no final do século XIX.

Seguindo esta linha de análise, podemos perceber a permanência de um pensamento maniqueísta arcaico no interior da sociedade moderna. Disseminou-se a compreensão de que a existência de uma realidade ruim, má, só poderia ser obra das forças maléficas, na sua eterna luta para a conquista do mundo e para a destruição do bem. Neste sentido se inserem os mitos conspirativos: os conspiradores seriam agentes maléficos, grupos sinistros cuja ação clandestina estaria provocando a destruição das boas tradições, dos bons valores, da boa sociedade e levando à implantação do "reino do mal".

É interessante observar que nos três modelos clássicos (maçons, jesuítas e judeus) há uma demonização explícita ou implícita das personagens. Nas versões mais extremadas, os conspiradores são apresentados como pactuantes com o demônio em pessoa, que estaria dirigindo a ação de seus delegados na terra.

Podemos citar uma historieta muito divulgada nos meios anti-semitas, elaborada pela primeira vez em um romance de meados do século XIX chamado Biarritz. Em determinada passagem há a narrativa de um suposto encontro entre líderes das doze tribos de Israel, realizado no cemitério de Praga. Após algum tempo de iniciada a reunião, tendo falado os principais líderes judeus, surge (à meia-noite, como não poderia deixar de ser), para participar do conluio, emergindo de uma tumba, o próprio filho das trevas (COHN, 1983).

Contudo, mesmo no caso das representa ções menos radicais há referências implícitas à presença das forças malígnas, freqüentemente através de recursos simbólicos. Assim, por exemplo, os conspiradores são normalmente apresentados trajando roupas negras; 
suas reuniões e ações sempre têm uma ambientação sinistra: na calada da noite, em lugares lúgubres como criptas e cemitérios, lançando mão da camuflagem e do embuste; são também associados a rituais tidos como satânicos pelo imaginário popular, como sacrifícios de vítimas inocentes, algumas vezes de crianças.

A persistência do pensamento maniqueísta revela a resistência à aceitação de um dos principais desdobramentos da modernidade, o "desencantamento do mundo", quer dizer, a compreensão do mundo como uma obra essencialmente humana, livre da ação de forças sobrenaturais. Na verdade, a questão é mais complexa. O que temos aqui é uma espécie de compromisso entre a "mentalidade" arcaica e a moderna (TAGUIEFF, 1992, p.17-38). Há a permanência do maniqueísmo, da divisão rígida entre bem e mal, do entendimento das forças malignas como atuantes e responsáveis pela ocorrência de coisas ruins. Porém, o mal é humanizado, é personificado em determinados grupos humanos bem concretos e palpáveis, e como tal poderia e deveria ser combatido.

De uma maneira geral, portanto, a elaboração e o apelo popular dos mitos conspirativos podem ser entendidos como decorrência das tensões provocadas pelo advento da modernidade. $\mathrm{O}$ mito da conspiração judaica mundial deve ser interpretado como parte deste quadro mais amplo, embora provavelmente tenha se constituído na versão mais influente e, certamente, na de mais conhecidas e terríveis conseqüências.

\section{Análise do discurso}

O anti-semitismo é uma realidade paradoxal. Constituiu-se no bojo da modernidade, mais precisamente, no período contemporâneo, tratando-se, portanto, de um fenômeno eminentemente moderno. Contudo, sua inspiração básica está relacionada ao temor e às tensões desencadeadas pela emergência do mundo moderno. Como veremos na conclusão do texto, o ódio ao judeu é explicado, ao menos em par- te, pelo fato de sua imagem ter sido associada às principais características da modernidade (MAYER, 1990, p.278-282).

Basicamente, foram utilizadas quatro fontes para a análise da construção discursiva do mito da conspiração judaico-comunista: os "Protocolos dos Sábios do Sião", os textos do líder integralista Gustavo Barroso, o "Plano Cohen" e o livro "Minha Luta", de Adolf Hitler.

É importante uma análise mais detida dos "Protocolos", em virtude desta obra ter se constituído num dos principais veículos divulgadores do mito. O texto foi publicado originalmente na Rússia, nos primeiros anos do século XX. No entanto, só ganhou notoriedade, no interior do Império Czarista, após a ocorrência da Revolução de 1905, e, em âmbito mundial, na sequiência da I Guerra e da Revolução Bolchevique. Tal fato se deveu ao conteúdo do texto, supostamente profetizador de catástrofes relacionadas a guerras e revoluções.

Não há dúvidas atualmente quanto ao fato dos "Protocolos" serem uma falsificação, provavelmente elaborada por agentes da polícia secreta czarista, com o intuito de combater as idéias liberais e revolucionárias que grassavam na Rússia naquele momento. A falsificação foi comprovada na década de 1920 por um repórter do jornal The Times, que descobriu ser a obra uma adaptação de um livro do francês Maurice Joly, escrito na década de 1860 (ROSENFELD, 1976).

Vejamos o argumento do livro, para tornar compreensível seu intuito conservador e para perceber sua inverossimilhança. O texto é apresentado no formato de uma série de conferências ou discursos proferidos por um suposto sábio judeu dirigindo-se a outros elementos de alta estirpe judaica. Os diálogos vão revelando, aos poucos, a existência de uma vasta conspiração, dirigida por sábios do Sião e voltada para o domínio do mundo. O plano judaico vinha sendo sistematicamente colocado em prática havia muitos séculos e aproximava-se agora o momento de sua con- 
clusão, quando a civilização baseada nos valores cristãos seria finalmente destruída e estabelecido o reino de Israel.

A revelação contida nos "Protocolos" era espetacular: as grandes mudanças sofridas pelo mundo europeu nos últimos séculos, que estavam lentamente destruindo as bases da sociedade tradicional (leia-se cristã), provocando transformações sociais intensas e o questionamento dos valores estabelecidos, não se constituíam num processo gratuito. Havia uma "mão oculta", uma força sinistra condutora de todos aqueles acontecimentos tidos como nefastos. Na verdade, a destruição do mundo tradicional e a conseqüiente emergência da modernidade teriam sido planejadas e executadas sub-repticiamente pela conspiração judaica.

O texto atribuído aos supostos sábios judeus demonstrava que a conspiração era responsável, entre outras coisas:

.pela corrupção das mentes dos jovens através da divulgação do ensino subversivo;

.pela destruição da família e da Igreja;

.pelo estímulo à procura por vícios e luxo;

.por criar distrações nocivas voltadas para as massas, principalmente jogos e competições esportivas;

.pelo enfraquecimento dos corpos através da disseminação de vírus de várias enfermidades;

.por criar o descontentamento universal e o ódio entre as classes; .pelo despojamento da aristocracia de suas terras e tradições; .pela desmoralização das classes superiores e dos religiosos; .por levar a indústria a esgotar a agricultura;

.pelo estímulo a todas as utopias impraticáveis; .por envenenar as relações entre os povos;

.pela concessão do sufrágio com o fim de entregar o poder a incapazes;

.pela derrubada da monarquia e instauração de repúblicas em vários países;

.por gerar monopólios, controladores dos meios econômicos; .pela destruição da estabilidade financeira;

.por criar o caos, enfim (BARROSO, 1989, p.51).
Em suma, atribuía-se aos judeus a culpa pela destruição do mundo tradicional, baseado nos valores do cristianismo e da nobreza. Evidentemente, destaca-se neste discurso um forte acento conservador, revelado pela demonstração de um medo profundo em relação às transformações associadas à modernidade e um forte saudosismo em relação ao Ancien Regime.

Mas, qual seria a motivação a impulsionar a obra destrutiva do judaísmo? A explicação se encontraria em seu desejo de dominar o mundo. Os judeus precisavam destruir as bases da civilização cristã para tornar possível a implantação de seu reinado, que passaria pelo domínio completo e pela escravização da humanidade. A conspiração judaica, na essência, seria motivada por intenções maléficas, conduzida por forças do mal.

Voltemos, brevemente, à discussão empreendida no item anterior: os mitos conspirativos são inspirados por uma visão maniqueísta da realidade, pela crença na existência de forças diabólicas empenhadas em fazer o mal. A ansiedade causada por problemas concretos, associada ao medo da mudança e ao temor em relação ao futuro, torna viável e atraente a idéia de que tal realidade negativa só poderia ser obra de espíritos maléficos e, no limite, demoníacos.

Podemos passar agora à análise do vínculo entre anti-semitismo e anticomunismo, aproximação operada pelo discurso do mito conspirativo entre a ação judaica e a comunista. Nos "Protocolos dos Sábios do Sião" a questão comunista não está colocada de forma sistemática. Acusa-se os judeus de serem os responsáveis pelo ódio entre as classes, pelo estímulo às utopias e por defenderem o coletivismo, mas, não há menção direta ao comunismo. Devemos levar em conta o fato dos "Protocolos" terem sido escritos antes da Revolução de 1917, acontecimento efetivamente responsável por uma maior divulgação mundial dos ideais comunistas.

O contexto produzido pelo impacto da Revolução bolchevique, associado ao quadro social caótico 
emergente na Europa do imediato pós-Grande Guerra, forneceu combustível para o estabelecimento de uma extraordinária onda anti-semita e anticomunista, dando origem ao mito da conspiração judaico-comunista, na verdade uma atualização para o século XX do anti-semitismo oitocentista.

Neste sentido, foi no período crítico compreendido pelas décadas de 1920 e 1930 que teve origem a campanha anti-semita mais violenta jamais conhecida, a qual estava, obviamente, vinculada à criação e ascensão ao poder dos movimentos nazi-fascistas. Significativamente, imediatamente após a Grande Guerra e a Revolução bolchevique apareceram as primeiras edições ocidentais dos "Protocolos", até então conhecidos apenas na Rússia. A profundidade da crise e a complexidade dos problemas enfrentados tornava atraente o recurso ao mito conspirativo: alguém, alguma força terrível, deveria ser responsável pela situação. Para muitos, a realidade estaria confirmando a existência do maligno plano dos "sábios do Sião": não diziam os "Protocolos" que a trama judaica passava pela disseminação do ódio entre os povos, pelo fomento às revoluções e pela quebra da estabilidade financeira e econômica?

Neste contexto, os nazistas destacaram-se como os principais disseminadores do anti-semitismo, um dos elementos básicos de seu ideário. Lançaram mão de uma tradição presente há muito na cultura européia, mas, atualizaram-na, através da incorporação de novos elementos. A introdução da temática comunista foi uma das principais inovações e sua importância foi muito grande, a ponto de podermos falar na constituição do mito da conspiração judaico-comunista. Os dois "elementos", judeu e comunista, foram aproximados pelo discurso nazista e transformados nos grandes vilões, artífices e verdadeiros promotores do caos e da destruição.

A proposta comunista não seria uma utopia positiva e generosa, voltada para a conquista do bem estar dos povos e da igualdade social. Por trás da fa- chada de um ideal aparentemente bem intencionado esconderia-se uma sórdida trama judaica, inspirada por desígnios terríveis. Nas palavras de Hitler:

Devemos enxergar no bolchevismo russo a tentativa do judaísmo, no século vinte, de apoderar-se do domínio do mundo, justamente da mesma maneira por que, em outros momentos da história, êle procurou, por outros meios, embora intimamente parecidos, atingir os mesmos objetivos. A sua inspiração tem raízes na sua maneira de ser. (...) o judeu não renuncia espontaneamente a sua aspiração de uma ditadura mundial (...) Ou êle será repelido por forças exteriores para outro caminho ou o seu desejo de domínio universal só desaparecerá com a extinção da raça. (HITLER, 1983, p.411)

Assim, o comunismo seria apenas mais um embuste dos judeus - o mais recente, pois no passado usaram outros -, na sua eterna luta pelo domínio do mundo. Segundo Hitler, o elemento judaico utilizava-se do discurso democrático e popular para convencer as massas e alcançar o poder, mas, conquistado seu objetivo, lançava fora o disfarce e se transformava "no judeu sanguinário e tiranizador de povos" (HITLER, 1983, p.211).

Há um aspecto muito importante a ser ressaltado: na medida em que constrói uma força maléfica terrível, o discurso maniqueísta evidencia a necessidade da existência de forças do bem, cuja ação é indispensável para anular o mal. Quanto mais terrível este for, maior vigor devem possuir os "cavaleiros da luz", mais dura deverá ser a atuação dos defensores do bem. Daí tornava-se perfeitamente justificável a necessidade da constituição de aparatos políticos repressivos e totalitários, bem como o recurso à violência e à guerra, apresentadas como medidas preventivas contra a ameaça "judeo-bolchevique”. Passava a ser legítimo o ataque à Rússia (URSS), país escravizado pelo judaísmo após a revolução, pois tratava-se de destruir o bastião do mal. Escritas em 1923, as palavras de Hitler podem ser interpretadas como uma revelação de que seus planos para a Rússia já estavam traçados vinte anos antes da guerra: 
É tão impossível à Rússia livrar-se do jugo judaico por suas próprias forças, como ao judeu manter o contrôle sôbre o vasto império, ainda por muito tempo. Êle não é um elemento organizador, e sim antes um fermento de decomposição. O imenso império do oriente está prestes a ruir. O fim do domínio judaico na Rússia será também o fim da Rússia como Estado. Fomos escolhidos pelo destino para sermos testemunhas de uma catástrofe que será a mais formidável confirmação da verdade da teoria racial (HITLER, 1983, p.407).

No Brasil dos anos 30 encontramos também, particularmente entre os integralistas, elementos defensores de posições anti-semitas extremadas. ${ }^{2}$ Gustavo Barroso, advogado e ex-deputado, membro da liderança da AIB e um de seus mais destacados doutrinadores, tornou-se o principal divulgador do anti-semitismo no Brasil. Grande admirador de Hitler, inspirou-se no pensamento do chefe nazista e no texto dos "Protocolos" para compor seu próprio arsenal argumentativo contra os judeus. A versão brasileira dos "Protocolos", por sinal, foi editada e traduzida por Barroso, em 1934.

Em sua obra Gustavo Barroso também investiu na operação de associar comunismo e judaísmo, apresentando ambos como duas facetas do mal e, portanto, alvos a serem combatidos vigorosamente. Ele encarava o comunismo como a etapa final da conspiração judaica, seu ponto culminante, enquanto o passo anterior havia sido a implantação do capitalismo, igualmente obra dos judeus, cuja intenção era solapar e destruir a boa sociedade tradicional, baseada em valores cristãos e espirituais. À medida em que intensificava a exploração sobre as massas trabalhadoras, atiçando o ódio entre as classes, o capitalismo preparava o advento da sociedade comunista, largamente propagandeada pelos agentes judaicos.

\footnotetext{
${ }^{2}$ Ressalve-se que o tema era polêmico no interior da Ação Integralista Brasileira, alguns setores não concordavam em assumir o programa anti-semita. Cf. CARNEIRO, Maria Luiza Tucci. O Anti-semitismo na Era Vargas (1930-1945). 2 ${ }^{\text {a }}$ Ed. São Paulo, Brasiliense, 1995. p. 353-354.
}

Na perspectiva barrosiana, então, capitalismo e comunismo, no fundo, teriam a mesma origem judaica. Por um lado, isto seria evidenciado pela referência à presença de judeus à frente de ambos, por exemplo, Rothschild e Trotsky ${ }^{3}$. Por outro lado, suas características básicas seriam as mesmas, materialismo e internacionalismo ${ }^{4}$, tidas como essencialmente judaicas. Contudo, embora houvesse a tendência a aproximar capitalismo e comunismo através de sua caracterização como etapas de uma mesma conspiração, o comunismo era apresentado como pior, mais danoso.

No comunismo, a dominação judaica seria estabelecida em sua plenitude. Os elementos semitas teriam o poder absoluto, garantido pela instalação da ditadura, que lhes permitiria completar o trabalho de destruição dos principais pilares da boa sociedade: família, pátria, religião e propriedade individual:

O comunismo que agitadores estrangeiros, sobretudo judeus, aliados a brasileiros vendidos ou inconscientes, inimigos da Pátria, nos prometem, quer a destruição das pátrias, da propriedade e da família, a proletarização das massas e a materialização do homem em todos os sentidos. Tirando ao indivíduo suas crenças e tradições, sua vida espiritual e sua esperança em Deus, sua família que é sua projeção no Tempo, e sua propriedade - que é sua projeção no Espaço, arranca-lhe as forças de reação, todos os seus sen-

\footnotetext{
${ }^{3}$ Barroso se referia com mais freqüência aos comunistas judeus: "Karl Marx era judeu, duma familia rabinica-talmudista de Trèves. Engels era judeu, duma familia rabinica de Barmen. Lenine casou com uma judia. Os comissarios do povo na Rússia, na maioria, judeus. Bela Kun, judeu. Trotsky, judeu”. O integralismo de norte a sul. Rio de Janeiro, Civilização Brasileira, 1934, p.41. Nota-se o esforço para ligar todos os líderes comunistas mais conhecidos ao judaísmo. Mesmo Lênin, apesar de não ser judeu, teria se casado com uma judia. Pelo menos nos casos de Engels e Krupskaia a suposta ascendência judaica é polêmica.

${ }^{4} \mathrm{O}$ programa barrosiano, em contraposição, defendia o espiritualismo e o nacionalismo.
} 
timentos, deixa somente a fera humana e prepara-o, assim, para definitiva escravização ao capitalismo judaico internacional disfarçado em capitalismo de Estado (BARROSO, 1935a, p.14)

O "Plano Cohen" é um exemplo eloqüente de como foi forte a influência do anti-semitismo no Brasil da década de 1930. Tratava-se de um suposto plano comunista para a conquista do poder, "descoberto" pelo Exército às vésperas do golpe de 1937 e utilizado para legitimar a implantação da ditadura estadonovista, apresentada como necessária para a defesa contra o perigo comunista. Na verdade, o documento foi redigido pelo então capitão Olímpio Mourão Filho, que acumulava as funções de oficial do Estado-Maior do Exército e chefe do serviço de informações da AIB. ${ }^{5}$

A trama continha ingredientes típicos do imaginário anti-semita e anticomunista, bem como da mitologia conspirativa. O "plano" era uma conspiração urdida às escondidas por um pequeno grupo, mestre na arte da camuflagem ${ }^{6}$. As ações previstas tinham um caráter sinistro e traiçoeiro: terrorismo (explosão de bombas) e incêndios para criar caos e espalhar pânico entre a população, e a realização de sequiestros e assassinatos de personalidades importantes, visando desarticular a reação das autoridades.

\footnotetext{
5 Mourão reconheceu, anos mais tarde, a autoria do "Plano Cohen”, embora declarasse não ter sido responsável por sua manipulação política. De acordo com sua versão o trabalho serviria apenas para treinamento interno dos militantes integralistas, tendo sido enviado às altas patentes militares sem seu consentimento. SILVA, Hélio. A Ameaça Vermelha: o Plano Cohen. Porto Alegre, L\&PM, 1980.

${ }^{6}$ Há uma passagem risível: grupos de conspiradores deveriam se posicionar no topo dos prédios mais altos e, com metralhadoras, atirar sobre as ruas para semear o pânico. O plano previa, rocambolescamente, que as armas deveriam ser camufladas em caixas de violino. SILVA, Op. Cit., p.282.
}

A evidência mais clara de anti-semitismo, obviamente, se encontra no nome do suposto autor do plano. Cohen é um dos sobrenomes judaicos mais comuns e talvez exatamente por isso tenha sido escolhido. Inicialmente, Mourão Filho assinalou Bela Kuhn como o autor do plano. Era o nome de um conhecido comunista europeu de origem judaica, líder da fracassada Revolução húngara de 1919. Rabiscou, contudo, a primeira versão e optou pela forma Cohen, somente. Parece evidente que a intenção era vincular a atividade dos comunistas a uma conspiração de proporções internacionais e, ao mesmo tempo, associar sua imagem ao judaísmo internacional.

Analisando com cuidado o discurso da conspiração judaico-comunista observamos a existência de uma série de expressões verbais repetidas com freqüência. O caráter repetitivo de tais elementos discursivos não era casual: a repetição se fazia necessária para efeito de fixação da mensagem no imaginário popular. Como ensinava Hitler, o segredo para a conquista do apoio popular era escolher algumas poucas idéias - diríamos imagens -, simples, porém fortes, e divulgá-las exaustivamente através da propaganda.

Agrupamos as expressões componentes do discurso de acordo com a afinidade temática, privilegiando alguns elementos de maior destaque no imaginário antisemita e anticomunista. As fontes de onde foram retiradas algumas das expressões não foram mencionadas, para evitar um volume excessivo no corpo de notas:

Elementos destrutivos: "O comunismo internacional (...) destrói as Pátrias, as Famílias e as Religiões, arrancando ao proletário todos os seus elementos espirituais (...) escravizandoo depois"(BARROSO, 1935a, p.62); "ruína”; “desordem”; “poderosíssimo bando de criminosos".

Decadência, degeneração: "putrefação"; "barbárie comunista"; "depravados"; "degradação"; "aviltamento"; "bastardizar a raça"; "bacilos"; "vírus".

Forças do mal: "O comunismo é(...) alguma cousa alem duma doutrina. (...) Essa paixão é a paixão revolucionária, cuja raiz vamos encontrar no fundo das idades, na rebeldia luciferiana 
(...)”(BARROSO, 1938, p.11); "produto do inferno"; "organização diabólica"; "vampiros judeus".

Ação sub-reptícia: "a quintessência do perigo judaico é a camuflagem"; "ação às ocultas"; "formidável maquinação secreta"; "infiltração".

As armas dos conspiradores: "calúnias"; "corrupção"; "veneno"; "mentiras".

Objetivos: "Essa revolução mundial produzirá necessariamente o triunfo do Imperialismo Vermelho, que é o Imperialismo de Israel (...)”(BARROSO, 1938, p.39); “judeu sanguinário e tiranizador de povos"(HITLER, 1983, p.210); "hegemonia mundial"; "domínio mundial"; "domínio universal”; "escravização".

Materialismo: "O verdadeiro creador do comunismo marxista é o velho materialismo judaico que vêm desde muitos centenarios solapando os alicerces da civilização cristã "(BARROSO, 1934, p. 39-41); "o bezerro de ouro"; "culto do ouro".

Maniqueísmo: “(...) os tempos são chegados: o Cristo se acha em face do Anti-Cristo. Temos de escolher. Temos de optar. Roma ou Moscou. O Vaticano ou o Kremlin. Toda indefinição equivale a compactuar com o inimigo"(BARROSO, 1938, p.35); “A verdade inconteste é que o plano dos Protocolos foi ditado pelo Mal e êste, que o combate (o programa integralista), pelo Bem. A simples leitura comparada convence disso os menos perspicazes. Ao Brasileiro compete escolher entre os Protocolos e o Integralismo"(BARROSO, 1935a, p.133).

Esta é uma pequena amostra dos temas e das expressões mais recorrentes do discurso e do imaginário construído pelos divulgadores do mito da conspiração judaico-comunista. Poderiam ser citados muitos outros exemplos, mas isto ocuparia um espaço além do razoável, tendo em vista os objetivos do trabalho. Além do mais, o material selecionado é suficiente para propiciar uma percepção adequada das formas discursivas usadas na constituição do mito. Fica evidenciada com clareza a virulência do ataque aos "judeo-comunistas" e à sua suposta conspiração, permitindo-nos fazer uma idéia do "ambiente" extremista vivido à época.

\section{Análise da iconografia}

O material iconográfico nos fornece outro rico filão para analisar o discurso e o imaginário em tela ${ }^{7}$. Publicações de diversos tipos - livros, panfletos, jornais, revistas -, na maioria das vezes produzidas na década de 1930, traziam impressas representações gráficas (desenhos, caricaturas, etc.) de inspiração anti-semita.

O judeu era sempre representado com as feições do estereótipo semita: cabelos e barba negra, assim como os olhos, e o famoso nariz adunco. Suas roupas eram sempre negras, provavelmente para fortalecer a imagem sinistra que se desejava sugerir. Várias caricaturas apresentam esta figura estereotipada abraçando ou agarrando o globo terrestre, representando, obviamente, o plano judaico de domínio mundial. Em uma delas o judeu está enterrando as unhas e rasgando a superfície do planeta, e das fissuras escorre sangue... Há um cartaz feito para uma exposição na Alemanha nazista que apresenta uma variação deste tema: o judeu sinistro está agarrando o território alemão, que conserva debaixo de um dos braços; em uma mão, estendida, há algumas moedas e, na outra, segura um chicote (CARNEIRO, 1995, p.453). A imagem simboliza a alegada exploração da Alemanha pelos judeus: através do dinheiro e do chicote, símbolo da escravidão, o perverso judeu controlaria a nação alemã.

Contudo, as imagens mais curiosas são as representações zoomórficas, reproduções que misturam formas animais com formas humanas, numa alusão implícita às características não-humanas atribuídas

\footnotetext{
${ }^{7}$ Pretendemos seguir a proposta de Panofsky, que destaca a importância de se interpretar as imagens, e não apenas descrevê-las. A esta tentativa de incursionar em profundidade no sentido das representações imagéticas ele chama interpretação iconológica. Apud KOSSOY, Boris. Fotografia e História. São Paulo, Ática, 1989. p. 65-80.
} 
aos judeus. Importante ressaltar que os animais escolhidos partilham características comuns: na tradição popular são tidos como repelentes, asquerosos e/ou assustadores. Os exemplos mais freqüentes são: polvo, aranha, serpente, abutre, morcego e sanguessuga.

Analisando mais detalhadamente cada uma das figuras animais mencionadas, podemos perceber que as características a elas atribuídas remetem a aspectos da imagem do judeu construída pelo discurso antisemita:

Abutre - carniceiro, oportunista, alimenta-se da matéria destruída. Há um desenho onde aparece um judeu-abutre observando uma cidade cristã destruída. Ele observa a destruição com prazer e parece estar se preparando para servir-se dos despojos (COHN, 1983).

Polvo - animal cheio de tentáculos, sugerindo onipresença. Trata-se da forma usada com mais freqüência para representar a conspiração internacional judaica.

Aranha - a imagem da teia e da própria aranha era associada à idéia de práticas traiçoeiras, de armadilhas. Existe uma representação gráfica clássica mostrando um judeu-aranha tecendo uma teia sobre o globo terrestre.

Morcego (vampiro) e sanguessuga - figuras que sugerem exploração, parasitismo.

Serpente - animal repelente, perigoso e mortal. Algumas das edições dos "Protocolos" traziam na capa representações de serpentes, freqüentemente desenhadas envolvendo a Terra ${ }^{8}$.

Há um outro aspecto interessante em relação às representações da serpente. Tradicionalmente, esse animal representa a sedução, a sensualidade, como no mito bíblico de Adão e Eva. Podemos perceber este elemento também no anti-semitismo. A conspiração judaico-comunista é, algumas vezes, ligada à imagem da sedução:

O judeuzinho de cabelos negros espreita, horas e horas, com um prazer satânico, a menina inocente que êle macula com o seu

\footnotetext{
${ }^{8}$ Na capa da edição sueca de 1924 foi reproduzido um desenho interessante: uma serpente, tendo como cabeça a figura do judeu estilizado, abraça o globo terrestre. CARNEIRO, Op. Cit..p.359.
}

sangue, roubando-a ao seu povo. Não há meios que êle não empregue para estragar os fundamentos raciais do povo que êle se propõe vencer. (...) segundo um plano traçado, vai corrompendo mulheres e mocinhas (...). (HITLER, 1983, p. 210)

O perigo judaico, portanto, também estaria ligado à sedução e esta, por seu turno, guardaria vínculos com o demônio ("prazer satânico") e com o mal. No imaginário popular, bem como nas representações bíblicas, a sedução da serpente seria obra das forças do mal. Neste sentido, a associação da conspiração judaico-comunista à imagem da serpente levava à mobilização de temores e arquétipos profundamente enraizados na cultura popular.

Não seria possível encerrar a discussão sobre a iconografia anti-semita sem fazer menção à utilização da estrela de David. Ela aparece em várias representações, constituindo-se num dos principais símbolos dos judeus e do judaísmo. Na primeira edição brasileira dos Protocolos, por exemplo, a capa traz um desenho de uma serpente, com uma estrela de David ladeando sua cabeça.

O motivo da estrela foi muito utilizado para simbolizar a afinidade entre judaísmo e comunismo:

O estudo dos mitos e dos símbolos pode conduzir ao encontro da Verdade que êles ocultam. A svástica hitleriana leva-nos aos ários, avós dos germanos; o fascio mussolínico leva-nos à grandeza de Roma; o sigma integralista leva-nos aos primitivos cristãos gregos. A estrêla vermelha dos Soviets leva-nos ao judaismo talmúdico. (BARROSO, 1935b, p.197)

A estrela de David foi associada à estrela vermelha da bandeira soviética, sugerindo a existência de uma decisiva inspiração judaica por trás do ideário comunista. Algumas representações iconográficas também exploram o tema, mostrando as duas estrelas (soviética e de David) em situação de proximidade. 


\section{Conclusão}

Para finalizar, abordaremos duas questões de fundamental importância para o entendimento do mito da conspiração judaico-comunista:

A quem ou a que servia o mito e o próprio antisemitismo?

Como se explica o fato de tantas pessoas terem nele acreditado?

Parece claro que tanto a "visão conspirativa da história" quanto o preconceito contra os judeus tiveram uma origem popular. Porém, sem nenhuma dúvida, houve uma manipulação política consciente por parte de determinados líderes políticos, que souberam explorar os temores populares para se fortalecerem e/ou combaterem as idéias radicais e revolucionárias, e através de suas ações criaram e amplificaram a doutrina e o movimento anti-semita.

Existem exemplos ilustrativos a tal respeito. Como já foi dito, há fortes indícios de que os "Protocolos" tenham sido forjados por encomenda da OKHRANA, polícia política do Estado czarista russo, interessada em mobilizar os setores sociais mais atrasados contra as aspirações reformistas e revolucionárias. Hitler, grande conhecedor do comportamento das massas populares, compreendeu que sua mobilização seria mais fácil se houvesse um inimigo poderoso a quem temer:

A conquista da alma do povo só é realizável quando, ao mesmo tempo que se luta para os próprios fins, se aniquila o adversário dos mesmos. (...)

A nacionalização de nossa massa popular só é realizável quando, na luta positiva para a conquista da alma do nosso povo, ao mesmo tempo esmagarmos os seus envenenadores internacionais. (HITLER, 1983, p.217)

Transformar o judeu/comunista em inimigo assustador, em encarnação do mal e do demônio, legitimava a existência de uma força antagônica representante do bem. Contra um inimigo terrível seria indispensável constituir-se uma poderosa falange dos "defen- sores do bem", que teriam de usar força e violência para vencer o "bom combate".

Evidentemente, a mitologia conspirativa se prestava também ao combate às idéias revolucionárias, particularmente ao comunismo. Ao contrário de idealistas bem intencionados, como se auto-proclamavam, os comunistas seriam agentes perversos da conspiração mundial judaica, cujo fim último era a escravização do mundo. Deveriam, portanto, ser combatidos sem trégua, sendo aceitáveis todas as armas e meios.

Contudo, devemos tomar cuidado para não criar uma mitologia conspirativa ao contrário, ou ceder a uma análise simplória, que levaria a encarar o antisemitismo e o anticomunismo como obra de forças malignas. Mesmo reconhecendo a existência de intenções e práticas manipulatórias, não se deve excluir a possibilidade de muitos líderes anti-semitas e anticomunistas acreditarem sinceramente em sua doutrina. De outro modo, como entender as ordens dadas em alguns setores do front oriental, ao final da II Guerra, quando a situação militar do exército alemão era desesperadora, para priorizar o transporte ferroviário de prisioneiros judeus aos campos de extermínio, em detrimento do transporte de tropas? Alguns líderes nazistas realmente encaravam os judeus como inimigos perigosos e pensavam em sua destruição como um benefício a seu país e ao mundo.

Outro aspecto fundamental é tentar entender como foi possível tantas pessoas serem envolvidas pelo mito e acreditarem na veracidade de uma conspiração judaica objetivando a implantação do comunismo. $\mathrm{Na}$ verdade, os mitos, particularmente os modernos, não podem ser criados no vazio. Sua construção e aceitação dependem de alguma verossimilhança, de algum contato com o real. No início do trabalho relacionamos a emergência dos mitos conspirativos ao temor e ansiedade provocados pelas transformações do mundo moderno. Porém, falta ainda explicar por que a figura do judeu se prestou tão bem ao papel de "bode 
expiatório", responsabilizado por todos os problemas e foco contra o qual o ódio e o medo foram dirigidos.

Na realidade, os judeus possuíam algumas características que tornaram possível a construção do mito:

. a força de sua cultura e de sua identidade, mantida e reproduzida através dos séculos;

. a manutenção de uma forte presença no mundo dos negócios e das finanças;

. sua posição destacada na produção intelectual;

. o fato de terem uma inserção internacional;

. uma certa propensão a apoiar projetos reformistas e/ou revolucionários.

Quanto ao último ponto é preciso evitar uma generalização abusiva. Sempre houve membros conservadores no interior da comunidade judaica. No entanto, durante o período áureo das reformas e revoluções, aproximadamente entre o final do século XVIII e início do XX, os judeus se posicionaram com mais freqüência ao lado das mudanças. E a razão é simples: como grupo marginalizado na sociedade tradicional cristã viam com bons olhos as propostas de liberdade e igualdade entre os homens, que soavam como a promessa de sua emancipação do gueto (COURTOIS \& LAZAR, 1987, p.138-141).

Não é sem motivo, portanto, que os judeus atraíram o ódio dos grupos insatisfeitos e temerosos em relação às transformações do mundo moderno. Eles pareciam representantes perfeitos da modernidade: políticos e intelectuais radicais, empresários modernos e seres cosmopolitas, quer dizer, sem pátria. $\mathrm{O}$ internacionalismo atribuído aos judeus era um elemento particularmente odiado pelos setores conservadores, que depositavam na nação e no nacionalismo suas melhores esperanças de construir uma identidade segura num mundo encarado como caótico e em decomposição. $\mathrm{O}$ “judeu sem pátria” era visto com temor e desprezo, pois era encarado como um possível destruidor da integridade e da pureza da nação.
Quanto ao comunismo, tido como o ponto culminante da ação das forças destrutivas e maléficas, sua vinculação com a figura do judeu também não foi construída no vazio. Havia algo de real sustentando o mito. O número de judeus ligados aos movimentos comunistas era muito expressivo, bem como sua influência. Na liderança bolchevique e nos quadros do PC russo a presença judaica era grande. Além do muito conhecido Trotsky, destacavam-se também Zinoviev, Kamenev, Radek, Litvinov, Piatnitski, Kaganovich, Iezhov, Lozovski, entre outros. Na Internacional Comunista acontecia o mesmo. Há um dado que ajuda a avaliar o poder de atração das idéias de esquerda sobre a comunidade judaica, particularmente no contexto da luta antifascista: dos cerca de 32.000 voluntários das brigadas internacionais na guerra civil espanhola, aproximadamente $25 \%$ (de 7 a 8 mil) eram de origem judaica (COURTOIS \& LAZAR, 1987, p.140).

Voltando os olhos para o Brasil, encontramos na história do comunismo brasileiro uma destacável participação de judeus nas fileiras do PCB. Vários tiveram projeção nacional, entre eles Leôncio Basbaum, Jacob Gorender, Maurício Grabois e Salomão Malina. O PCB, inclusive, foi presidido por um deles, Malina, fato raríssimo na história brasileira9 .

O partido possuía algumas organizações de base as células da estrutura leninista - compostas exclusivamente de judeus ${ }^{10}$. Após a tentativa revolucionária de 1935 a polícia desarticulou uma dessas bases, com a prisão de 23 pessoas. $\mathrm{O}$ documento policial com o re-

\footnotetext{
${ }^{9}$ Salomão Malina desempenhou o cargo nos anos 1980. Foi, provavelmente, o único judeu a ocupar a presidência de um partido político em toda a história brasileira.

${ }^{10}$ Em Belo Horizonte, a título de exemplo, a base judaica funcionou até os anos 1970. Depoimento de Jayme Goifman, setembro/outubro de 1996. Acervo do Grupo de História Oral da FAFICH/UFMG.
} 
gistro das detenções diz que pertenciam todos à organização revolucionária BRAZCOR, ligada ao PCB. ${ }^{11}$

Enfim, alguns dados da realidade ajudam a entender porque o mito se viabilizou. $\mathrm{O}$ fato de uma parcela expressiva da comunidade judaica ter abraçado os valores modernos e lutado por sua implantação, inclusive os ideais revolucionários, tornou possível a construção e, principalmente, a divulgação do mito da conspiração judaica e judaico-comunista.

No entanto, tal constatação não pode ser utilizada para responsabilizar os judeus pela criação do mito, isto seria absurdo. Tampouco torna justificável ou

\section{Bibliografia}

BARROSO, Gustavo. (org.) Os Protocolos dos sábios do Sião. Porto Alegre, Ed. Revisão, 1989.

BARROSO, Gustavo. O integralismo de norte a sul. Rio de Janeiro, Civilização Brasileira, 1934.

BARROSO, Gustavo. O que o integralista deve saber. $2^{\mathrm{a}}$ Ed. Rio de Janeiro, Civilização Brasileira, 1935(a).

BARROSO, Gustavo. A palavra e o pensamento integralista. Rio de Janeiro, Civilização Brasileira, 1935(b).

BARROSO, Gustavo. Comunismo, cristianismo e corporativismo. Rio de Janeiro, ABC, 1938.

CARNEIRO, Maria Luiza Tucci. O Anti-semitismo na Era Vargas (1930-1945). 2 a Ed. São Paulo, Brasiliense, 1995.

COHN, Norman. El mito de la conspiración judía mundial. Madrid, Alianza Editorial, 1983.

COURTOIS, Stéphane \& LAZAR, Marc. Le communisme. Paris, M.A. Editions, 1987.

11 "27 de novembro de 1935. Ilmo Sr. Dr. Director da Casa de Detenção:

De ordem do Exmo Sr. Chefe de Polícia, faço-vos apresentar os comunistas: Abrahão Rosemberg, Jayme Gardelsran, Waldemar Gutnik, Jacob Gria, Rubens Goldberg, Armando Guelman, Henrique Jviblaski, Jayme Sterneberg, José Hachternwaker, Waldemar Roiteberg, Nicolau Marinoff, Joseph Fridman, Carlos Garfunkel, José Veveiss, Matias Janosai, Moisi Lipes, Cesar aceitável o surgimento dos movimentos contra os judeus e o judaísmo. A constatação é que algumas características existentes no interior da comunidade judaica, observáveis notadamente no período anterior à Segunda Guerra, facilitaram a propagação do anti-semitismo. É aí que reside o "contato" da mitologia conspirativa com a realidade.

Atribuir, porém, aos judeus responsabilidade pela criação da modernidade e pela explosão revolucionária, acreditando terem eles conspirado longa e secretamente em prol destes objetivos é entrar decididamente no terreno do mito, no sentido de pura fabulação.

ELIADE, Mircea. Mito e realidade. São Paulo, Perspectiva, 1972.

GIRARDET, Raoul. Mitos e mitologias políticas. São Paulo, Cia. das Letras, 1987.

HITLER, Adolf. Minha luta. São Paulo, Ed. Moraes, 1983.

KOSSOY, Boris. Fotografia e História. São Paulo, Ática, 1989.

LEFEBVRE, Georges. O grande medo de 1789. Rio de Janeiro, Campus, 1979.

MAYER, Arno. A força da tradição. São Paulo, Cia. das Letras, 1990. ROSENFELD, Anatol. Mistificações literárias: "Os Protocolos dos Sábios do Sião”. São Paulo, Perspectiva, 1976.

SILVA, Hélio. A Ameaça Vermelha: o Plano Cohen. Porto Alegre, L\&PM, 1980.

TAGUIEFF, Pierre-André. Les Protocoles des Sages de Sion: introduction à l'étude des Protocoles. Paris, Berg, 1992.

WEBER, Eugen. França fin-de-siècle. São Paulo, Cia. das Letras, 1988.

Zibenberk, David Lerer, Sgulin Seko Vrabel, Moyses Kava, Nute Goifman, João Schachter e Baruh Zell, os quaes ahi ficarão recolhidos, á disposição daquella autoridade, afim de serem expulsos do territorio nacional, por perigosos á ordem publica e nocivos aos interesses do paiz.

Ass. Affonso Henrique de Miranda Corrêa (Delegado Especial de Segurança Política e Social)" - Arquivo Geral da Polícia Civil do Distrito Federal. Prontuário n ${ }^{0}$ 15.709. 